\title{
Lignocellulosic Biofuels and Grass Plants Used in Production of Pellets
}

\author{
Rasma Platace ${ }^{1}$, Aleksands Adamovics ${ }^{2}$, Inguna Gulbe ${ }^{3},{ }^{1-3}$ Latvia University of Agriculture
}

\begin{abstract}
Use of plant biomass in energy production is one of the preconditions to compensate growing shortage of fossil resources; therefore the research covered production of pellet samples and testing of quality parameters thereof. The study aimed at researching hemicellulose indicators in osier and poplar pellets, lignin content in perennial crops (depending on fertiliser types, norms), parameters characterising pellet content variations (their evaluation and optimisation depending upon the proportions of pellet components) as well as characterisation of lignocellulose parameters.
\end{abstract}

Keywords - cellulose, grass plants, hemicellulose, lignin, pellets.

\section{INTRODUCTION}

There are many crops or crop residues in agriculture that could be used for the production of liquid, solid or gaseous fuels [1]. While the most promising crops utilised in the production of bioenergy (biofuel) are perennials since they can be harvested for several years in a row without reseeding and yield high biomass with satisfactory quality $[2 ; 3 ; 4]$.

It is possible to control biomass quality with various management methods. Growing conditions, grass specie, cutting frequency and fertilization leave the highest influence on the biomass production $[5 ; 6]$.

Plant biomass is a major energy source. A distinction is made between the lignocellulosic biomass (wood, straw, green waste etc.), biomass with high sugar and starch content (beetroot, sugar cane, wheat, maize etc.) and oleaginous biomass (rapeseed, soya, sunflower etc.). Mentioned biomass types are transformed into biofuels with help of various methods [7].

Within the framework of energy generation strategy, in which residue/waste biomass is processed at production sites, companies may have their own energy resource as they are generating waste.

Among the possible vegetal biomass treatment processes pyrolysis is one of the most suitable, as it takes advantage of both great flexibility and relatively easy control over the product yield and characteristics.

The basic idea behind this research is a verification of the feasibility of a steam-assisted pyrolysis of biomass aimed at the production $[8 ; 9]$.

In its turn, general trend in the pellet production faced in Europe (incl. Baltics) is a lack of traditional raw materials (e.g., conifer sawdust generated in wood processing). Researches dedicated to the alternative biofuel sources lately have been very topical, and the issue is often discussed in international forums concerning problems when using biomass in energy production. Currently biomass has been receiving increased interest as a renewable energy source within the context of climate change and mitigation of climate impacts. This renewable energy is based on a short-cycle crops and energy crops which could contribute to the modern society's energy needs. According to the type of raw material used and conversion technology applied, biofuels can be divided into the two main categories of first and second generation of biofuels (and the potential of the third) [10].

Biomass is a general term used for all organic materials derived from plants. From the chemical viewpoint it is a composite material, consisting of a mixture of hemicellulose, cellulose, lignin and extracts, and affected by the chemical structure of the species [11]. Today it is the second most commonly used energy source having $14 \%$ contribution to the world energy consumption, as compared to $12 \%$ of coal and $15 \%$ of gas $[10,12 ; 13]$.

The major combustible component of non-food energy crops is cellulose and the second one - lignin. Non-food energy crops are more efficient, as compared to the edible ones (having great content of starch). Hemicellulose is a cellulose-related polysaccharide that comprises about $20 \%$ of the biomass in most plants.

As biomass is primarily composed of hemicellulose, cellulose and lignin, it can be decomposed at temperature between $225-325^{\circ} \mathrm{C}, 305-375^{\circ} \mathrm{C}$ and $250-500^{\circ} \mathrm{C}$, respectively [14]. It has been found out that decomposition temperature of cellulose is much higher than that of lignin, which makes a larger amount of cellulose become more volatile [12]. This leads to the fact that the bigger the lignin composition, the greater the amount of char produced or carbonaceous residues, because of a lower thermal degradation.

Biomass as a raw material has important advantages in combustion - high volatility of the fuel and high reactivity of both fuel and resultant char.

Gravimetric techniques (isothermal and non-isothermal) have generally been used to investigate reactivity of carbonaceous materials. These techniques have been selected in this work to evaluate physical and chemical properties, generating a variety of correlations that show the optimal conditions for the types of biomass that can be utilized in the production of biofuels $[1 ; 7]$.

Lignocellulosic biomass mainly consists of three polymeric components: hemicellulose, cellulose and lignin. Lignin is an amorphous polymer made by different phenolic compounds and it is the main component of cell walls. 
TABLE I

COMPOSITION OF POTENTIAL LIGNOCELLULOSIC BiOMASS RESOURCES

\begin{tabular}{|c|c|c|c|c|}
\hline Lignocellulosic materials, biomass & Cellulose, $\%$ & Hemicellulose, \% & Lignin, $\%$ & References \\
\hline Hardwoods stems & $40-55$ & $24-40$ & $18-25$ & \multirow{2}{*}{ [22] } \\
\hline Softwood stems & $45-50$ & $25-35$ & $25-35$ & \\
\hline Grasses & $25-40$ & $35-50$ & $10-30$ & [22] \\
\hline Switchgrass & $37-45$ & 29-31.4 & $12-19$ & {$[22 ; 23 ; 24 ; 25 ; 26]$} \\
\hline Big bluestem & 37 & 28 & 18 & [27] \\
\hline Miscanthus & 43 & 24 & 19 & {$[2 ; 28]$} \\
\hline Reed canary grass & 24 & 36 & $\mathrm{n} / \mathrm{a}$ & [29] \\
\hline Timothy & 28 & 30 & $\mathrm{n} / \mathrm{a}$ & {$[30 ; 31]$} \\
\hline Tall fescue & 25 & 25 & 14 & [32] \\
\hline Corn stover & 38 & 26 & 19 & {$[23 ; 24 ; 32]$} \\
\hline Wheat straw & 38 & 29 & 15 & {$[32 ; 33 ; 34]$} \\
\hline Alfalfa & 27 & 12 & $\mathrm{n} / \mathrm{a}$ & [27] \\
\hline Forage sorghum & 34 & 17 & 16 & [32] \\
\hline Sawdust & $43-46$ & $25-34$ & $26-28$ & [1] \\
\hline Newspaper & $40-55$ & $25-40$ & $18-30$ & [22] \\
\hline Poplar & $42-49$ & $16-23$ & $21-29$ & [22] \\
\hline Hardwood & $40-48$ & $19-25$ & $22-25$ & \\
\hline Softwood (coniferous wood) & $35-43$ & $21-30$ & $22-25$ & {$[35]$} \\
\hline Wheat straw & 32 & 37 & 18 & ] \\
\hline Miscanthus & 40 & 34 & 18 & \\
\hline
\end{tabular}

Lignin holds together cellulose and hemicellulose fibres and gives support, resistance and impermeability to the plant.

It is estimated that every year approximately 5 billion tons of cellulose are formed in the nature. It has been estimated that around $7.5 \times 1010$ tonnes of cellulose are consumed and regenerated every year [34]. It is thereby the most abundant organic compound in the world. Cellulose mass in cells of different plants varies between $50 \%$ and $70 \%$. Until now, the most commonly used source of cellulose is wood (wood fibre), as well as cotton, hemp, flax, jute, wheat straw etc. and even roots (rutabaga etc.) [35]. Almost pure cellulose is present in cotton ( $90 \%)$; flax and hemp mainly consists from cellulose as well. Cellulose content in hemp depends on its specie, climatic conditions and agro-technical measures applied [36].

Table 1 summarizes the composition of lignocellulose present in the most common sources of biomass.

Perennial grasses display many beneficial energy crop attributes. In the USA there has been increasing interest in their use in respect to the environmental impact which is generally considered to be positive [2]. Perennial and herbaceous energy crops offer a significant opportunity to improve agricultural sustainability through the crop diversification, decreased erosion, and improved water quality, as compared to the traditional annual crop system [36].

Primary fuel characteristics that testify their suitability for combustion are: total energy produced, total moisture content and chemical content of the ash. Ash content and chemical indicators are important in the combustion process, because they can contribute to the formation of slag that reduce boiler efficiency and increase costs. Concentration of particular minerals varies depending on the plant specie and plant part. Qualitative parameters of harvested biomass are impaired by the presence of weeds [37].

Plant age or growth phase at harvesting as well as content of other minerals also have significant influence [38]. To avoid biomass quality problems associated with summer harvests, it is recommended to harvest plants during winter or spring following the growing season [39].

The objective of our study was evaluation of quality parameters; characterisation of hemicellulose indicators in osier and poplar pellets; investigation of lignin content in perennial grass plants depending on fertiliser types and norms; experimental research of parameters characterising pellet content mixtures, evaluation and optimisation thereof depending on the proportions of pellet components; as well as characterisation of lignocellulose (cellulose, hemicellulose and lignin) parameters; and comparison of the acquired lignocellulose values in pellet biomass with findings of other researchers.

This work aims at designing versatile and reliable tool that may be used for calculations, and it will be later integrated in a rigorous model, which will allow estimating combustion behaviour of waste plant biomass.

\section{MATERIALS AND METHODS}

The study covered research of following energy crops used for the fuel (pellet) production: poplar (Populus tremula L.), culmiferous plants - reed canary grass (RCG) (Phalaris arundinacea L.); tall fescue (Festuca arundinacea Schreb.) 
specie: 'Fawn'; festulolium (Festulotium) specie: 'Vetra' (L.multiflorum x F.arundinacea); meadow fescue (Festuc pratensis Huds.); timothy (Phleum pratense L.).

Samples (RCG variety 'Marathon' at N-90 kg ha-1 dose of chemical fertilizer) for the study were taken at Latgale Centre of Agriculture Science on 06.10.2010. Whereas cultivated energy plant (poplar) was collected in Vežaiči Agricultural Research Institute Centre (Lithuania) on 15.10.2010. Energy crops were grown in the Training and Research Farm 'Pēterlauki' of Latvia University of Agriculture, using 5 grass plant groups and treating them with 9 different fertilisers fertiliser variants (kg ha-1): 1) NOP0K0; 2) P80K120 (F background); 3) F+N30; 4) F+N60; 5) F+N90; 6) F+N120; 7) $\mathrm{F}+\mathrm{N} 150$; 8) F+N180; and 9) vermicompost $10 \mathrm{t}$ ha-1. Each tested combination was repeated three times. Soil type: sod calcareous ( $\mathrm{pHKCl} 6.7$ ), containing available $\mathrm{P} 52 \mathrm{mg} \mathrm{kg}-1$, $\mathrm{K} 128 \mathrm{mg} \mathrm{kg}-1$, organic matter content 21 to $25 \mathrm{~g} \mathrm{~kg}-1$ in the soil, main fertiliser (background) - P2O5- 80; K20- $120 \mathrm{~kg}$ ha-1. The total seeding rate was 1000 germinant seeds per $1 \mathrm{~m}^{2}$. Usage type: mowing two-three times.

Pellets were made of $100 \%$ natural ingredients - chopped poplar and chopped RCG biomass. They have cylindrical shape and they are approximately as thick as a pencil. Fuel consists of single components and two components. Singlecomponent pellets: (I) poplar, (II) RCG and two-component pellets: (I) in proportion $1 / 3$ ( $1 \mathrm{RCG}+3$ poplar); (II) in proportion $1 / 1$ ( $1 \mathrm{RCG}+1$ poplar); (III) in proportion $3 / 1$ (3 $\mathrm{RCG}+1$ poplar).

Within the pellet manufacturing process the energy plant biomass is chopped and ground in the laboratory mill ЭM-3A УХЛ 4.2, and afterwards powder produced in a mill is formed into a pellet with the hand press 'IKA WERKE'.

Pellet samples were tested for various chemical indicators cellulose, hemicellulose, lignin, neutral detergent fibre (NDF) content and acid detergent fibre (ADF) content; while in grass plant biomass - lignin content was measured.

Lignin content and ADF faction in energy crop pellets was determined in compliance with the LVS EN ISO 13906: 2008., NDF faction - with LVS EN ISO 16472: 2006, cellulose and lignin was measured with the help of forage analyses, procedures in the Agricultural Scientific Laboratory for Agronomic Analysis of the Latvia University of Agriculture.

Determination of NDF takes place as follows: samples are treated with neutral detergent (ND) solution and thermally stable alpha amylase that solvents highly digestible proteins, lipids, sugars, starch and pectin, leaving insoluble fibres (cellulose, hemicellulose, lignin). The sample is boiled in the solution for 1 hour, afterwards filtrated, washed and dried. After the weight loss the NDF content is calculated. Calculation of ADF is performed as follows sample is treated with acid detergent (AD) solution $(0.5 \mathrm{~mol} / \mathrm{l}$ $\mathrm{H}_{2} \mathrm{SO}_{4}$ ), leaving cellulose, lignin and insoluble proteins. The sample is boiled in the solution for 1 hour, afterwards filtrated, washed and dried. After the weight loss the ADF content is calculated.
Measurement or calculations of particular chemical content take place as follows: lignin - the sample acquired after determination of ADF is treated with $72 \% \mathrm{H}_{2} \mathrm{SO}_{4}$, after the weight loss the lignin content is measured; hemicellulose = NDF - ADF; and cellulose $=$ ADF - lignin .

For each sample three parallel experiments were carried out. The correlations were analyzed as linear or polynomial regressions, and graphs were made using MS Office program Excel.

\section{RESULTS AND DISCUSSION}

The research shows that the lowest cellulose content (36\%) is in RCG biomass, the highest - in poplar (40.87\%), while osier indicates $40.77 \%$. Among pellets from several energy crops the highest cellulose content was recorded in RCG/osier pellets (1/3) and RCG/poplar pellets (3/1) - 38.84\% and $40.05 \%$, respectively (see Fig. 1).

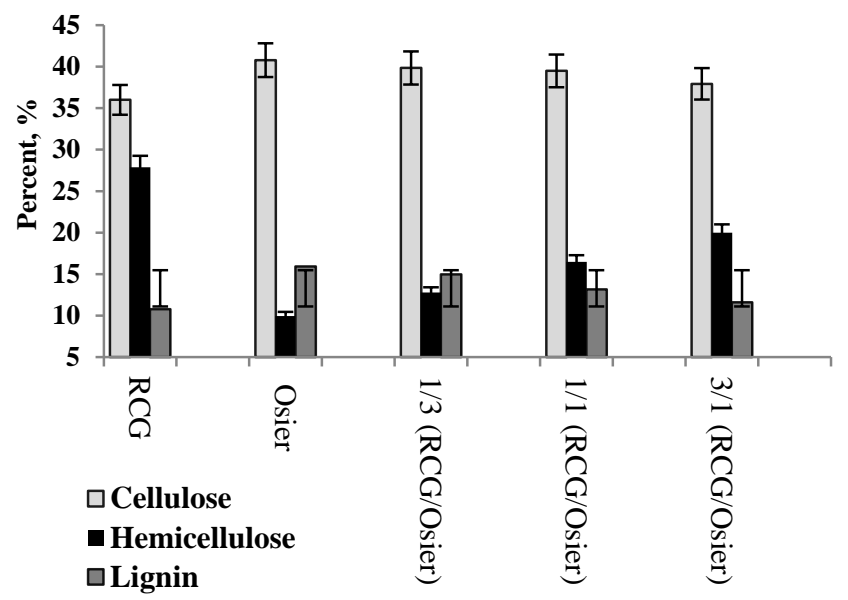

Fig. 1. Cellulose, hemicellulose and lignin content in RCG and osier pellets

When RCG is added to osier or poplar pellets, a reduction in the lignin content was recorded, and it was the lowest in pellets made of grass plants in proportion 1/3. Lignin content in such RCG/poplar pellets dropped by $2.39 \%$ and by $0.96 \%$ in RCG/osier pellets.

The average lignin content in grass plants comprises $7.5 \%$, in poplar - $19.67 \%$, and in osier $15.93 \%$, therefore it is advisable to produce pellets from grass plant biomass together with wood.

When adding RCG to osier or poplar pellets, a rise in the hemicellulose content was observed, and it was the highest in component proportion $1 / 3$. The content of hemicellulose in pellets made of RCG/poplar in mentioned proportion grew by $9.69 \%$ and in RCG/osier pellets - by $10.04 \%$.

Osier or poplar pellet supplementation with RCG resulted in an increase in the cellulose content, and it was the highest in pellets made of grass plants in proportion 3/1. Cellulose content in RCG/poplar pellets made of components in the above shares rose by $9.69 \%$, while in RCG/osier pellets - by $10.04 \%$. 
The study indicated that the highest hemicellulose content $(27.28 \%)$ is in RCG biomass and the lowest in poplar $(6.9 \%)$, while osier indicates $9.95 \%$. The highest hemicellulose content $(13.99 \%)$ among pellets from several energy crops was recorded in RCG pellets in proportion 3/1 with of osier. The best proportion of components in poplar pellets was $3 / 1$, as hemicellulose content in such samples accounted for $16.59 \%$ (see Fig. 2).

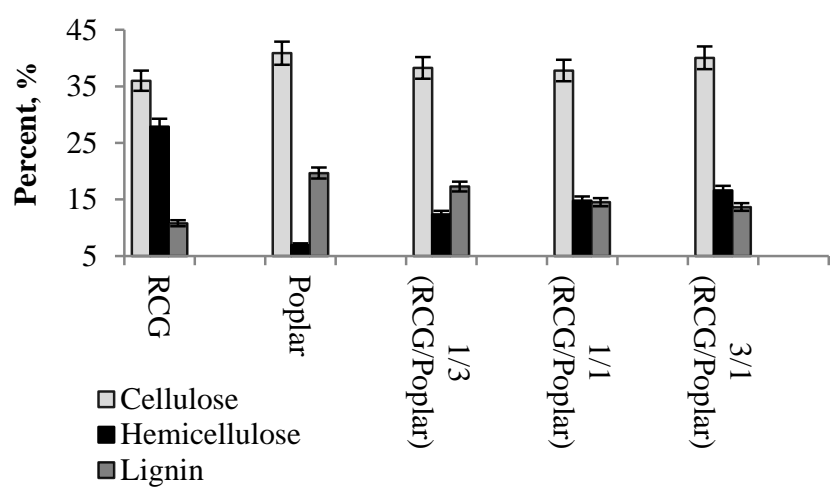

Fig. 2. Cellulose, hemicellulose and lignin content in RCG and poplar pellets

Within the research it was found out that the lowest lignin content $(10.78 \%)$ is in RCG biomass and the highest - in poplar (19.67\%), and osier indicates $15.93 \%$. The highest lignin content $(14.97 \%)$ among pellets made of several energy crops was recorded in RCG pellets in proportion $1 / 3$ with of osier, whereas the best proportion in RCG/poplar pellets was $1 / 3$, as their lignin content comprises $17.28 \%$.

Results of researches conducted by other scientists shows that: cellulose content comprises $30-50 \%$, while our study on average indicated $34.61 \%$ of the total dry matter; hemicellulose content comprises $20-40 \%$, but in our research $15.32 \%$ (slightly above the maximal value); lignin accounts for $15-25 \%$, but in our study $-14.6 \%$ (that is close to the data found by other researchers).

The research shows that the highest NDF faction (74.65\%) is in RCG biomass and the lowest $(64.44 \%)$ - in poplar, while osier indicates $66.65 \%$, and that the highest ADF faction $(46.78 \%)$ is in RCG biomass and the lowest - in poplar (57.54\%), whereas osier indicates $57.7 \%$ (see Fig. 3).

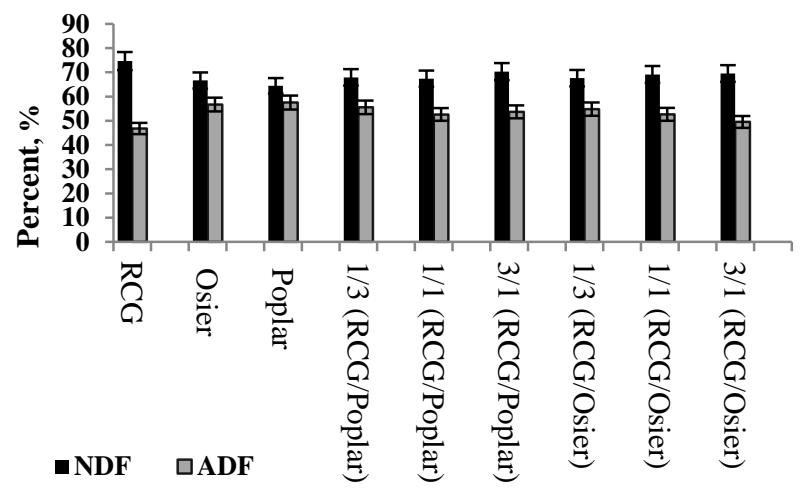

Fig. 3. NDF and ADF content in RCG and osier/poplar pellets
The highest NDF content (69.52\%) among pellets from several energy crops was recorded in RCG pellets in proportion 3/1 with of osier, while the best proportion with poplar was 3/1, as RXG/poplar pellets had 70.3\% of NDF.

Among pellets from several energy crops the highest ADF content $(54.81 \%)$ was recorded in RCG/osier pellets (in proportion 1/3), and the best component proportion in RCG/poplar pellets was $1 / 3$, as ADF content in them accounted for $55.55 \%$.

Evaluation of samples by fertilizer norms and types shows the highest lignin content in tall fescue without fertilizer $(6.06 \%)$, and, the crop indicates $5.69 \%$, when treated with fertilizer $\mathrm{F}+\mathrm{N} 150$, and $4.92 \%$ with application of vermicompost. Moreover, RCG without fertilizer indicates $5.03 \%, 5.41 \%$ with $\mathrm{F}+\mathrm{N} 90$ and $4.46 \%$ with vermicompost; festulolium without fertilizer shows $4.36 \%, 4.47 \%$ with $\mathrm{F}+\mathrm{N} 60$ and $4.23 \%$ with vermicompost (see Fig. 4).

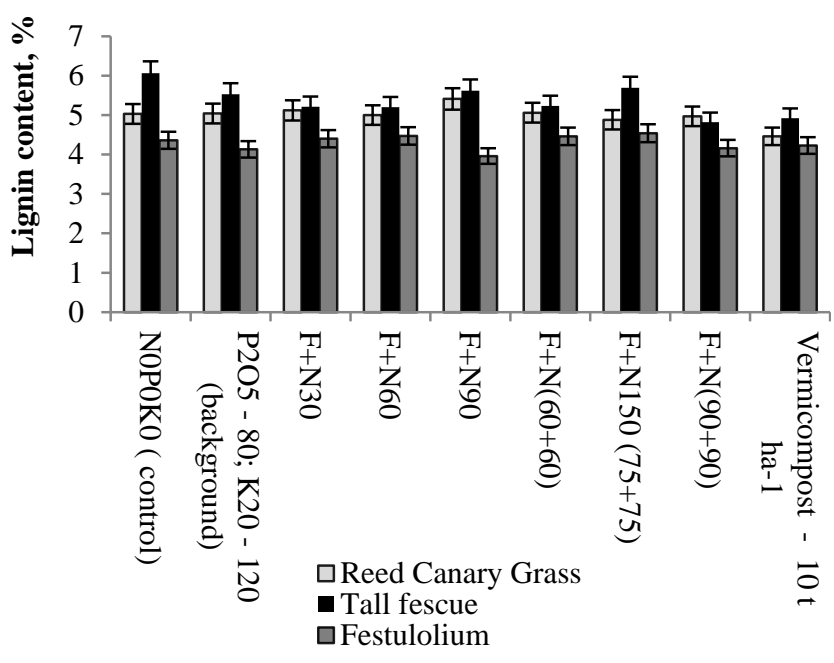

Fig. 4. Lignin content in RCG, festulolium and meadow fescue

In respect to the lignin content in other samples: timothy without fertilizer shows $8.29 \%$, with fertilizer F+30 - 8.31\%, and with vermicompost $-8.14 \%$; meadow fescue without fertilizer indicates $3.68 \%$, with $\mathrm{F}+\mathrm{N} 180-4.07 \%$, and with vermicompost $-4.13 \%$ (see Fig. 5).

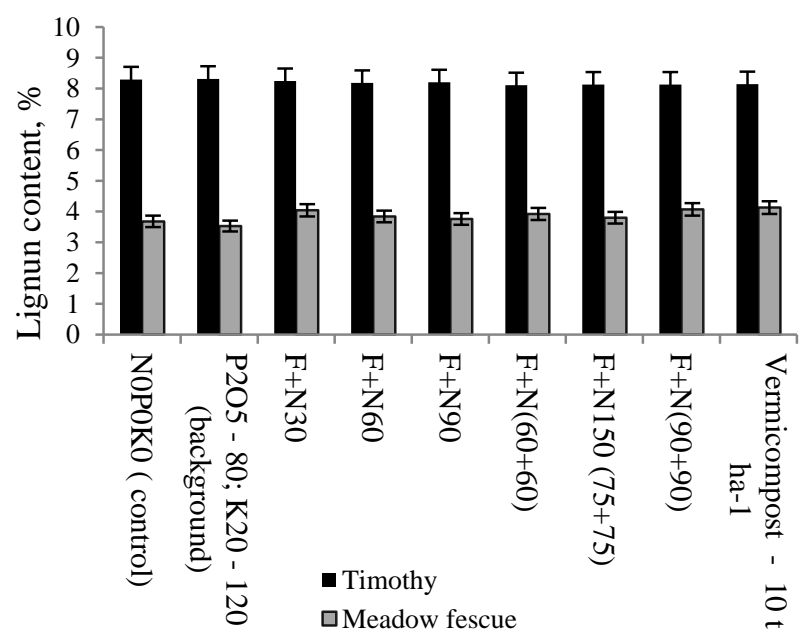

Fig. 5. Lignin content in timothy and meadow fescue 
Average indicators of the research show the highest lignin content in timothy $(8.19 \%)$, RCG $(5.00 \%)$, tall fescue $(5.36 \%)$, fescue ryegrass $(4.30 \%)$, and meadow fescue $(3.86 \%)$.

Lower lignin content was observed in grass plants harvested in summer (it varied between $8.29 \%$ and $3.53 \%$ ), while samples harvested in autumn showed $10.78 \%$. Lignin content in fall harvest was by $0.8 \%$ lower. To avoid problems with biomass quality associated with summer harvests, it is recommended to harvest plants during the winter or spring, following the growing season. Therefore, if RCG is used for pellet production, it is advisable to mow plants in autumn, after first frosts, and do it till spring, as well as to produce pellets from grass plant biomass that is mixed with wood (sawdust and woodchips).

\section{CONCLUSIONS}

(I) The study on the application of various fertiliser doses and norms on grass plants shows the best lignin content in samples not treated with fertilisers, while the most suitable indicators in samples treated with fertilisers were found when applying $\mathrm{F}+\mathrm{N} 30$ and $\mathrm{F}+\mathrm{N} 150$. Treatment of grass plants with vermicomost leads to the lowest lignin content; therefore, when producing pellets, it is advisable to supplement grass biomass with wood.

(II) The particular lignocellulose content slightly differs from the indicators found in other researches. Cellulose indicators acquired within the framework of this research mainly met the values discovered in other studies, while bethemicellulose and lignin indicators were slightly under the minimum value. Thus, as the lignocellulose values obtained meet the standards set for the production of pellets, the biomass pellets may be used for the production of biological fuel - pellets.

(III) The proportion of components the most suitable for pellet production was found at combination $1 / 3(\mathrm{RCG}+$ timber). As RCG has lower cellulose and lignin content, as compared to timber, when producing pellets, it is advisable to add up to $25 \%$ of RCG, and thus pellets should be produced from grass plant biomass together with wood (sawdust and woodchips).

\section{ACKNOWLEDGEMENTS}

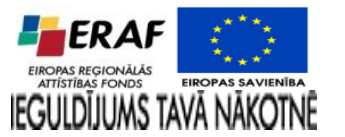

Participation in the conference is possible due to the financial support of the European Regional Development Fund project No.

2010/0294/2DP/2.1.1.2.0/10/APIA/VIAA/009

\section{REFERENCES}

1. Demirbas, A. Biorefineries: Current activities and future developments, Energy Conversion and Management, 2009, vol. 50, N 11, p. 2782-2801. http://dx.doi.org/10.1016/j.enconman.2009.06.035

2. Lewandowski, I., Scurlock, I.M.O., Lindvall E., et. al. The development and current status of perennial rhizomatous grasses as energy crops in the US and Europe. Biomass and Bioenergy, 2003, vol. 25, N 4, 335-361. http://dx.doi.org/10.1016/S0961-9534(03)00030-8

3. Heinsoo K., Hein K., Melts I., et. al. Reed canary grass yield and fuel quality in Estonian farmers' fields, Biomassand
Bioenergy, 2011, vol. 35, N 1, p. 617-625.

http://dx.doi.org/10.1016/j.biombioe.2010.10.022

4. Kryzeviciene, A. Perennial grasses as energy crops in Lithuania//Grassland Science in Europe.-2005, vol. 10, p. 178-181

5. Prochnow, A., Heiermann, M., Drenckhan, A., et. al. Seasonal Pattern of biomethanisation of grass from landscape man-Agement Agricultural Engineering International: The CIGR Ejournal, Manuscript EE 05011, vol. VII.,2005.<http://cigrejournal.tamu.edu/volume7.html> [Accessed 17.02.2013.]

6. Ruzgas, V., Kadžiulis, L. Terms and frequency of mowing cereal grasses in cases of different levels of fertilization with nitrogen. Žemdirbystė, Mokslo darbai, 1989, vol. 37, p. 123-134.

7. Saidur, R., Abdelaziz, E. A., Demirbas, A., et. al. A review on biomass as a fuel for boilers, Ren http://dx.doi.org/10.1016/j.rser.2011.02.015 ewable \& Sustainable Energy Reviews, 2011, vol.15, p. 2262-2289.

8. Cavaliere, A., de Joannon, M. Mild Combustion. Progress Energy and Combustion Science, 2004, vol. 30, N 4, p. 329-366. http://dx.doi.org/10.1016/j.pecs.2004.02.003

9. Lehmann, J., Gaunt, J., Rondon, M. Bio-char sequestration in terrestrial ecosystems. Mitigation and Adaptation Strategies for Global Change, 2006, vol. 11, N 3, p. 403-427.

10. Huang, Y. F., Kuan, W. H., Chiueh, P. T. A sequential method to analyze the kinetics of biomass pyrolysis. Bioresource Technology, 2011, vol. $102, \quad \mathrm{~N} \quad 19, \quad$ p. $9241-9246$. http://dx.doi.org/10.1016/j.biortech.2011.07.015

11. Di Blasi, C. Modeling chemical and physical processes of wood and biomass pyrolysis, Progress in Energy and Combustion Science, 2008, vol. 34, N 1, p. 47-90. http://dx.doi.org/10.1016/j.pecs.2006.12.001

12. Shen, D. K., Gu, S., Luo, K. H., et. al. Kinetic study on thermal decomposition of woods in oxidative environment, Fuel, 2009, vol. 88, p. 1024-1030. http://dx.doi.org/10.1016/j.fuel.2008.10.034 Dale, VH, Kline, KL, Wiens, J., et. al. Biofuels and Sustainability Reports. Washington, Ecological Society of America, Biofuels: Implications for Land Use and Biodiversity. 2010, http://www.esa.org/biofuelsreports/files/ESA\%20Biofuels\%20Report_V H\%20Dale\%20et\%20al.pdf, [Accessed 07.04.2013.]

13. White, J. E., Shen, D. K., Gu, S., et. al. Kinetic study on thermal decomposition of woods in oxidative environment, Fuel, 2009, vol. 88,p. 1024-1030.

14. Perlack, R.D., Wright, L.L., Turhollow, A.F., et. al. 2005. Biomass as feedstock for a bioenergy and bioproducts industry: the technical feasibility of a billion-ton annual supply. DOE/GO-102005-2135, April. U.S. Department of Energy and U.S. Department of Agriculture. http://dx.doi.org/10.1016/j.fuel.2008.10.034

15. Hamelinck, C.N.G., van Hooijdonk, Faaij, A.P.C. Ethanol from lignocellulosic biomass: Techno-economic performance in shortmiddleand long-term. Biomass Bioenergy , 2005, vol. 28, p. 384-410. http://dx.doi.org/10.2172/885984

16. Zhang X, Yu H, Huang H, Liu Y. Evaluation of biological pretreatment with white-rot fungi for the enzymatic hydrolysis of bamboo culms. Biodiversity and Biodegradation, 2004, vol. 60, p. 159-164. http://dx.doi.org/10.1016/j.biombioe.2004.09.002

17. Saha, B.C, Cotta, M.A. Enzymatic saccharification and fermentation of alkaline peroxide pretreated rice hulls to ethanol. Enzyme and MicrobialTechnology, 2007, vol. 41, p. 528-532.

18. Balan, V., Sousa, L.D.C., Chundawat, S.P.S ., et. al. Enzymatic digestibility and pretreatment degradation products of AFEX-treated hardwoods (Populusnigra). Biotechnology Progress, 2009, vol. 25, p. 365-375. http://dx.doi.org/10.1016/j.enzmictec.2007.04.006

19. Howard, R.L., Abotsi, E., Jansen van Rensburg E.L., et. al. Lignocellulose biotechnology: Issues of bioconversion and enzyme production. African Journal. Biotechnologu, 2003, vol. 2, p. 602-619. http://dx.doi.org/10.1002/btpr.160

20. Fengel, D., Wegener, G. Chemical composition and analysis of wood. In Wood: Chemistry, Ultrastructure, Reactions. Walter de Gruyter, Berlin, 1984, p. 26-65.

21. Sun, Y., Cheng J. Hydrolysis of lignocellulosic materials for ethanol production: A review. Bioresource and Technology, 2002, vol. 83, N 1, p. $1-11$.

22. Mani, S., Tabil, L.G., Sokhansanj, S. Effects of compressive force, particle size and moisture content on mechanical properties of biomass pellets from grasses. Biomass and Bioenergy, 2006, vol. 30, p. 648-654. http://dx.doi.org/10.1016/S0960-8524(01)00212-7 
23. Wiselogel, A.E., Agblevor, F.A., Johnson, D.K. Compositional changes during storage of large round switchgrass bales. Bioresource and Technology, 1996, vol. $56, \quad$ p. 103-109. http://dx.doi.org/10.1016/j.biombioe.2005.01.004

24. Mulkey, V.R., Owens, V.N., Lee. D.K. Management of switchgrassdominated Conservation Reserve Program lands for biomass production in South Dakota. Crop Science, 2006, vol. 46, p. 712-720. http://dx.doi.org/10.1016/0960-8524(95)00171-9

25. Lemus, R., Brummer, E.C., K.J. Moore, N.E. et. al. 2002. Biomass yield and quality of 20 switchgrass populations in southern Iowa, USA. Bioresource Technology. 2002, vol. 23, p. 433-720.

26. Jefferson, P.G., McCaughey, W.P., May, K., et. al. 2004. Potential utilization of native prairie grasses from western Canada as ethanol feedstock. Canadian J Plant Science, 2004, vol. 84, p. 1067-1075. http://dx.doi.org/10.4141/P03-157

27. Kurakake, M., Kisaka, W., Ouchi, K., et. al. Pretreatment with ammonia water for enzymatic hydrolysis of corn husk, bagasse, and switchgrass. Applied Biochemistry and Biotechnology, 2001, vol. 90, p. 251-259. http://dx.doi.org/10.1385/ABAB:90:3:251

28. Jung, H.G., Mertens, D.R., Payne. A.J. Correlation of acid detergent lignin and klason lignin with digestibility of forage dry matter and neutral detergent fiber. Journal of Dairy Science, 1997, vol. 80, p. 1622-1628. http://dx.doi.org/10.3168/jds.S0022-0302(97)76093-4

29. Alvo, P., Savoice, P., Tremblay, D., et. al.. A system approach for evaluation of ethanol production based on forages. Bioresource Technology, 1996, vol. 56, p. 61-68. http://dx.doi.org/10.1016/09608524(95)00179-4

30. Claessens, A., R. Michaul, R., Belanger, G.A.., et. al. Characteristics of timothy genotypes divergently selected for fiber traits. Crop Science, 2004, vol. 44, p. 81-88. http://dx.doi.org/10.2135/cropsci2004.0081

31. DOE (U.S. Department of Energy) Biomass feedstock composition and property database. Department of Energy, Biomass Program, 2006, .http://www.eere.energy.gov/biomass/progs/search1.cgi, [Accessed 35.04.2013.]

32. Ohgren, K., A. Rudolf, A., Galbe, M., et. al.. Fuel ethanol production from steam-pretreated corn stover using SSF at higher dry matter content. Biomass and Bioenergy, 2006. vol.30, p. 863-869. http://dx.doi.org/10.1016/j.biombioe.2006.02.002

33. Esteghlalian, A., Hashimoto, A.G. Fenske, J.J., et. al. Modeling and optimization of the dilute-sulfuric-acid pretreatment of corn stover, poplar and switchgrass. Bioresource Technology, 1997, vol. 59, p. 129-136. http://dx.doi.org/10.1016/S0960-8524(97)81606-9

34. Kicherer, A. Biomasseverbrennung in Staubfeuerungen - technische Moglichkeiten und Schadstoffemissionen, Dusseldorf, 2006,

http://books.google.lv/books?id=j_Mq_PWymmsC\&pg=PA43\&lpg=PA4 $3 \& \mathrm{dq}=1996 .+$ Kicherer, + A. + biomass\&source $=$ bl\&ots $=$ WUzzfgR4XF\&si $\mathrm{g}=$ oaRTOzhZiiU3TuJ8BZq9EuoOYZs\&hl=lv\&sa=X\&ei=FcqRUensG6 WO4ASm-[Accessed 17.04.2013.]

35. Tolbert V.R., Wright L.L., et. al. Environmental enhancement of US biomass crop technologies: research results to date. Biomass and Bioenergy, 1998, vol.15, p. 93-100. http://dx.doi.org/10.1016/S09619534(98)00005-1

36. Fuksa, P., Kocourková, D., Veselá, M. Weed infestation influence on chemical composition of silage maize (Zea mays L.). Forage Conservation. 2003, VúŽV Nitra, pp. 78-79.

37. Landström, S., Lomakka, L., Andersson, S. Harvest in spring improves yield and quality of reed canary grass as a bioenergy crop. Biomass and Bioenergy, 1996, vol. 11, p. 333-341. http://dx.doi.org/10.1016/09619534(96)00041-4

38. Hadders, G., Olsson, R. Harvest of grass for combustion in late summer and in spring, Biomass and Bioenergy, 1997, vol.12, p. 171-17 http://dx.doi.org/10.1016/S0961-9534(96)00047-5

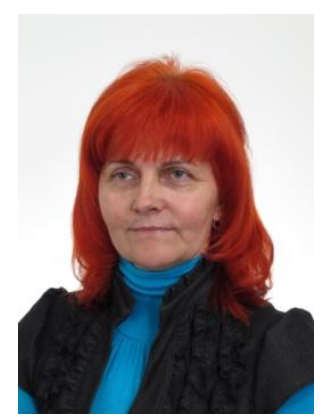

Rasma Platace, $\mathrm{PhD}$ student, Mg. sc. env., researcher in Institute of Agrobiotechnology, Latvia University of Agriculture, Master's degree acquired in 2011. Major field of study grassland management, research methodology in agronomy.

Doctoral Student in Latvia University of Agriculture located in Jelgava, and Gardener in Berzaune rural municipality. Prior evaluating projects in Rural Support Service branch in city of Madona, Brigadier and Technician in cooperative society "Gaizinsš", and Brigadier in Latvian Agricultural Research Institute "Iedzēni". Some of the previous publications are: Assessment of factors influencing lignin content in energy crop pellets, 3rd World Conference Innovation and Computer Science (insode-2013) abstracts book; Assessment of chemical elements in reed canary grass (Phalaris arundinacea L.) dry matter, Crop breeding and management for environmentally friendly farming: research and achievements; Research interests prior and currently cover grass plants and chemical, physical characteristics thereof.

Address: Lielā iela 2, LV-3001, Jelgava, Latvia

E-mail: rasmins@inbox.lv

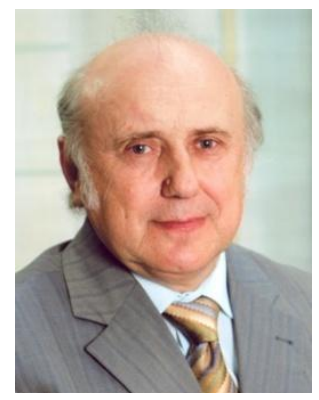

Aleksandrs Adamovics, Doctor of Agriculture. Major field of study grassland management, research methodology in agronomy.

Full Member of Latvian Academy of Agriculture and Forestry Sciences, Expert in Latvia Scientific Council, Vice Chairmen of promotion council "Field Crops", Director of doctoral study programme "Agriculture", Director of Institute of Agrobiotechnology, Latvia University of Agriculture. Research interests are related to various fields of agriculture.

Member of Latvia University of Agriculture

Senate and Convent

Address: Lielā iela 2, LV-3001, Jelgava, Latvia

Phone: 63005629 (at work), 28378044 (cell phone)

E-mail: aleksandrs.adamovics@1lu.lv

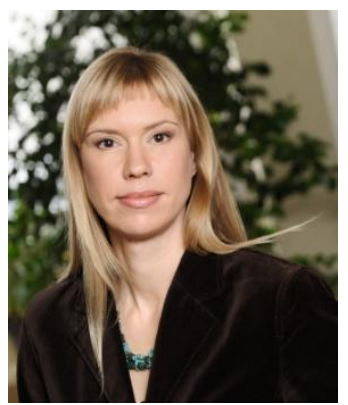

Inguna Gulbe, graduated from Agronomical Faculty of Latvian Agricultural Academy and obtained a qualification an agronomist in 1991. Another qualification in Market research was obtained in 1997 from the Latvian State University. Scientific degree in Economics and Social Sciences obtained from the Latvian Agricultural University in 2001 (Dr. Oec).

Since 2002, an assistant and associated professor at Latvian Agricultural University; currently also Head of Unit of the Latvian State Institute of Agrarian Economics. Fields of scientific interests cover agriculture and marketing.

Member of the Association of European Agricultural Economists and Society of Latvian Agronomists.

Address: Lielā iela 2, LV-3001, Jelgava, Latvia

E-mail: gulbe.inguna@inbox.lv 